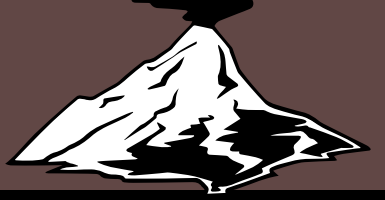

\title{
Overview for Geologic Field-Trip Guides to Volcanoes of the Cascades Arc in Northern California
}

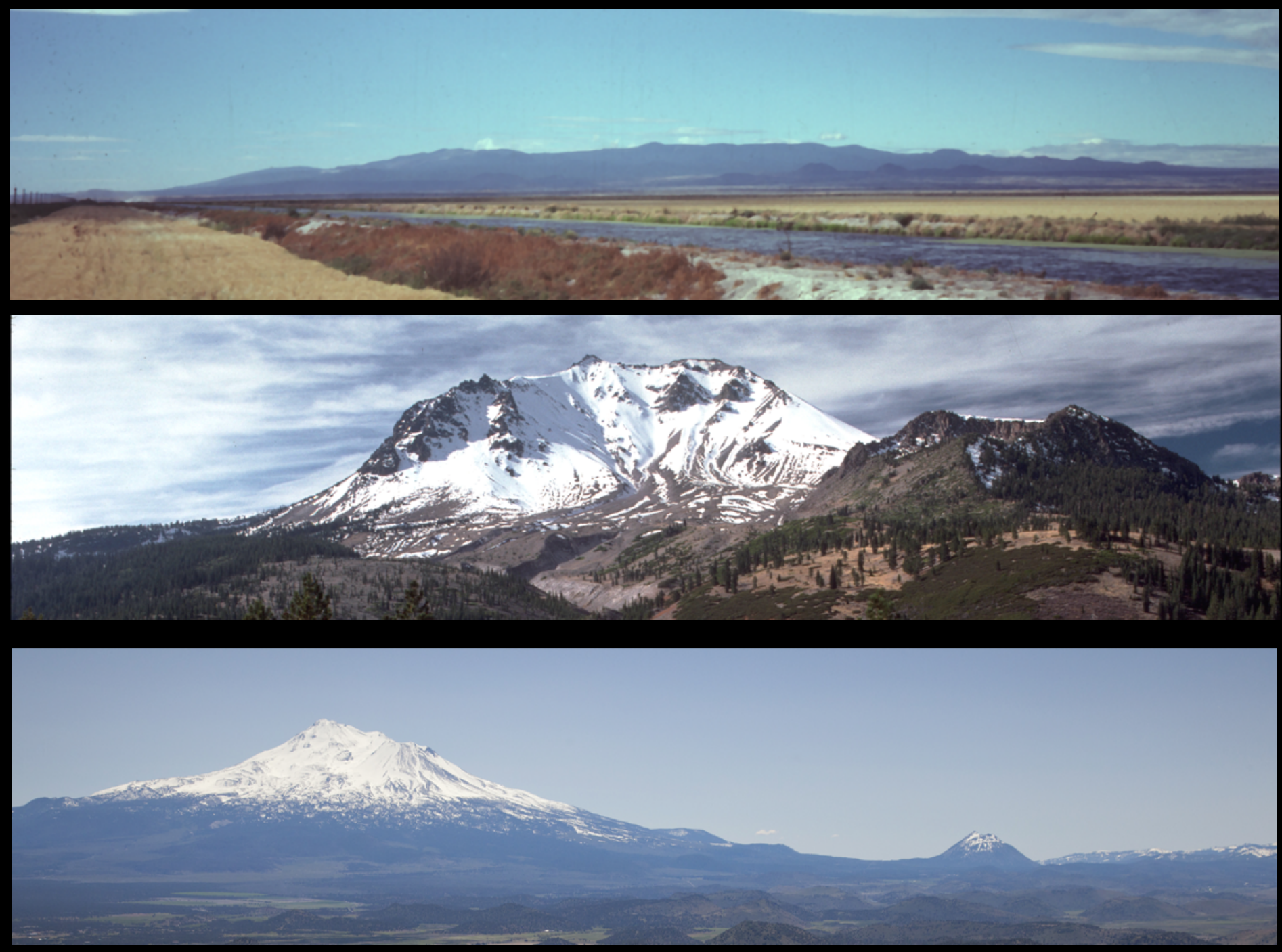

Scientific Investigations Report 2017-5022-K 
Cover: (Top) View of Medicine Lake volcano from the northeast. Photograph by Julie M. Donnelly-Nolan. (Middle) Photograph looking southwest from Emigrant Pass towards Lassen Peak (27 $\pm 1 \mathrm{ka})$ in the center and Crescent Crater (236 $\pm 1 \mathrm{ka}$ ) on the right. Photograph taken in 0ctober 1986 by M.A. Clynne. (Bottom) Aerial view from the north across the Shasta Valley sector-collapse debris-avalanche deposit, with Mount Shasta and Black Butte rising in the background. Photograph by J. Scurlock. 


\section{Overview for Geologic Field-Trip Guides to Volcanoes of the Cascades Arc in Northern California}

By L.J. Patrick Muffler, Julie M. Donnelly-Nolan, Timothy L. Grove, Michael A.

Clynne, Robert L. Christiansen, Andrew T. Calvert, and Juliet Ryan-Davis

Scientific Investigations Report 2017-5022-K 


\title{
U.S. Department of the Interior \\ RYAN K. ZINKE, Secretary
}

\section{U.S. Geological Survey William H. Werkheiser, Acting Director}

\author{
U.S. Geological Survey, Reston, Virginia: 2017
}

For more information on the USGS — the Federal source for science about the Earth, its natural and living resources, natural hazards, and the environment-visit https://www.usgs.gov or call 1-888-ASK-USGS.

For an overview of USGS information products, including maps, imagery, and publications, visit https://store.usgs.gov.

Any use of trade, firm, or product names is for descriptive purposes only and does not imply endorsement by the U.S. Government.

Although this information product largely is in the public domain, it may also contain copyrighted materials as noted in the text. Permission to reproduce copyrighted items must be secured from the copyright owner.

Suggested citations:

Muffler, L.J.P., Donnelly-Nolan, J.M., Grove, T.L., Clynne, M.A., Christiansen, R.L., Calvert, A.T., and Ryan-Davis, J., 2017, Overview for geologic field-trip guides to volcanoes of the Cascades Arc in Northern California: U.S. Geological Survey Scientific Investigations Report 2017-5022-K, 6 p., https://doi.org/10.3133/sir20175022K.

ISSN 2328-0328 (online) 


\section{Preface}

The North American Cordillera is home to a greater diversity of volcanic provinces than any comparably sized region in the world. The interplay between changing plate-margin interactions, tectonic complexity, intra-crustal magma differentiation, and mantle melting have resulted in a wealth of volcanic landscapes. Field trips in this series visit many of these landscapes, including (1) active subduction-related arc volcanoes in the Cascade Range; (2) flood basalts of the Columbia Plateau; (3) bimodal volcanism of the Snake River Plain-Yellowstone volcanic system; (4) some of the world's largest known ignimbrites from southern Utah, central Colorado, and northern Nevada; (5) extension-related volcanism in the Rio Grande Rift and Basin and Range Province; and (6) the spectacular eastern Sierra Nevada featuring Long Valley Caldera and the iconic Bishop Tuff. Some of the field trips focus on volcanic eruptive and emplacement processes, calling attention to the fact that the western United States provides opportunities to examine a wide range of volcanological phenomena at many scales.

The 2017 Scientific Assembly of the International Association of Volcanology and Chemistry of the Earth's Interior (IAVCEI) in Portland, Oregon, marks the first time that the U.S. volcanological community has hosted this quadrennial meeting since 1989, when it was held in Santa Fe, New Mexico. The 1989 field-trip guides are still widely used by students and professionals alike. This new set of field guides is similarly a legacy collection that summarizes decades of advances in our understanding of magmatic and tectonic processes of volcanic western North America.

The field of volcanology has flourished since the 1989 IAVCEI meeting, and it has profited from detailed field investigations coupled with emerging new analytical methods. Mapping has been enhanced by plentiful major- and trace-element whole-rock and mineral data, technical advances in radiometric dating and collection of isotopic data, GPS (Global Positioning System) advances, and the availability of lidar (light detection and ranging) imagery. Spectacularly effective microbeam instruments, geodetic and geophysical data collection and processing, paleomagnetic determinations, and modeling capabilities have combined with mapping to provide new information and insights over the past 30 years. The collective works of the international community have made it possible to prepare wholly new guides to areas across the western United States. These comprehensive field guides are available, in large part, because of enormous contributions from many experienced geologists who have devoted entire careers to their field areas. Early career scientists are carrying forward and refining their foundational work with impressive results.

Our hope is that future generations of scientists as well as the general public will use these field guides as introductions to these fascinating areas and will be enticed toward further exploration and field-based research.

Michael Dungan, University of Oregon Judy Fierstein, U.S. Geological Survey Cynthia Gardner, U.S. Geological Survey Dennis Geist, National Science Foundation

Anita Grunder, Oregon State University John Wolff, Washington State University

Field-trip committee, IAVCEI 2017 


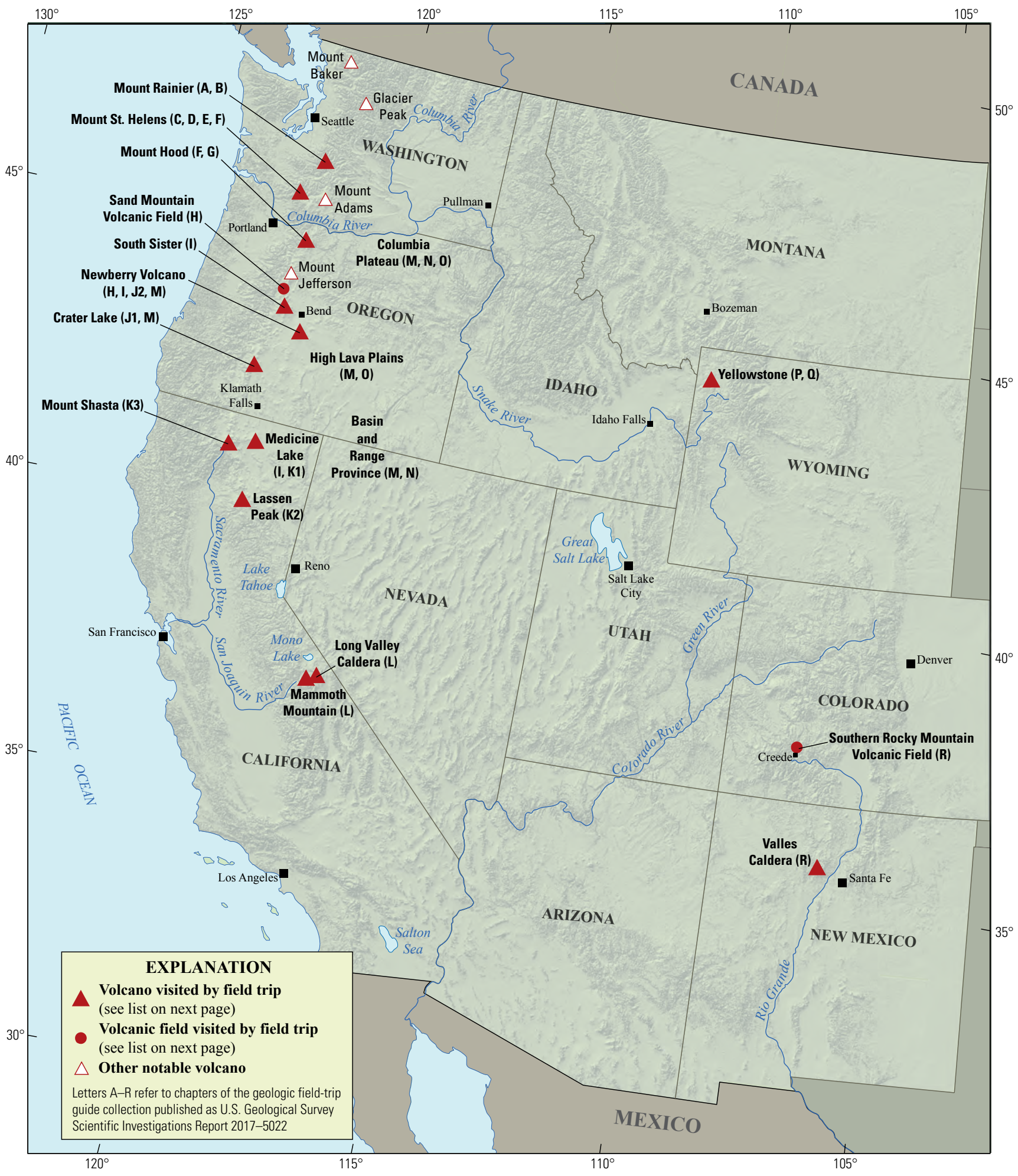

Map of the western United States showing volcanoes and volcanic fields visited by geologic field trips scheduled in conjunction with the 2017 meeting of the International Association of Volcanology and Chemistry of the Earth's Interior (IAVCEI) in Portland, Oregon, and available as chapters in U.S. Geological Survey Scientific Investigations Report 2017-5022. Shaded-relief base from U.S. Geological Survey National Elevation

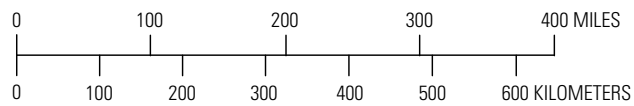
Dataset 30-meter digital elevation model data. 


\section{Chapter \\ letter Title}

A

B

C

D

E

F

G

H
Field-Trip Guide to Volcanism and Its Interaction with Snow and Ice at Mount Rainier, Washington

Field-Trip Guide to Subaqueous Volcaniclastic Facies in the Ancestral Cascades Arc in Southern Washington State-The Ohanapecosh Formation and Wildcat Creek Beds

Field-Trip Guide for Exploring Pyroclastic Density Current Deposits from the May 18, 1980, Eruption of Mount St. Helens, Washington

Field-Trip Guide to Mount St. Helens, Washington—An overview of the Eruptive History and Petrology, Tephra Deposits, 1980 Pyroclastic Density Current Deposits, and the Crater

Field-Trip Guide to Mount St. Helens, Washington—Recent and Ancient Volcaniclastic Processes and Deposits

Geologic Field-Trip Guide of Volcaniclastic Sediments from Snow- and Ice-Capped Volcanoes-Mount St. Helens, Washington, and Mount Hood, Oregon

Field-Trip Guide to Mount Hood, Oregon, Highlighting Eruptive History and Hazards

Field-Trip Guide to Mafic Volcanism of the Cascade Range in Central Oregon-A Volcanic, Tectonic, Hydrologic, and Geomorphic Journey

Field-Trip Guide to Holocene Silicic Lava Flows and Domes at Newberry Volcano, Oregon, South Sister Volcano, Oregon, and Medicine Lake Volcano, California

Overview for Geologic Field-Trip Guides to Mount Mazama, Crater Lake Caldera, and Newberry Volcano, Oregon

Geologic Field-Trip Guide to Mount Mazama and Crater Lake Caldera, Oregon

Field-Trip Guide to the Geologic Highlights of Newberry Volcano, Oregon

Overview for Geologic Field-Trip Guides to Volcanoes of the Cascades Arc in northern California

Geologic Field-Trip Guide to Medicine Lake Volcano, northern California, including Lava Beds National Monument

Geologic Field-Trip Guide to the Lassen Segment of the Cascades Arc, northern California

Geologic Field-Trip Guide to Mount Shasta Volcano, northern California

Geologic Field-Trip Guide to Long Valley Caldera, California

Field-Trip Guide to a Volcanic Transect of the Pacific Northwest

Field-Trip Guide to the Vents, Dikes, Stratigraphy, and Structure of the Columbia

River Basalt Group, Eastern Oregon and Southeastern Washington

Field-Trip Guide to Flood Basalts, Associated Rhyolites, and Diverse Post-Plume Volcanism in Eastern Oregon

Field-Trip Guide to the Volcanic and Hydrothermal Landscape of Yellowstone Plateau, Montana and Wyoming

Field-Trip Guide to the Petrology of Quaternary Volcanism on the Yellowstone Plateau, Idaho and Wyoming

Field-Trip Guide to Continental Arc to Rift Volcanism of the Southern Rocky Mountains-Southern Rocky Mountain, Taos Plateau, and Jemez Volcanic Fields of Southern Colorado and Northern New Mexico 


\section{Contributing Authors}

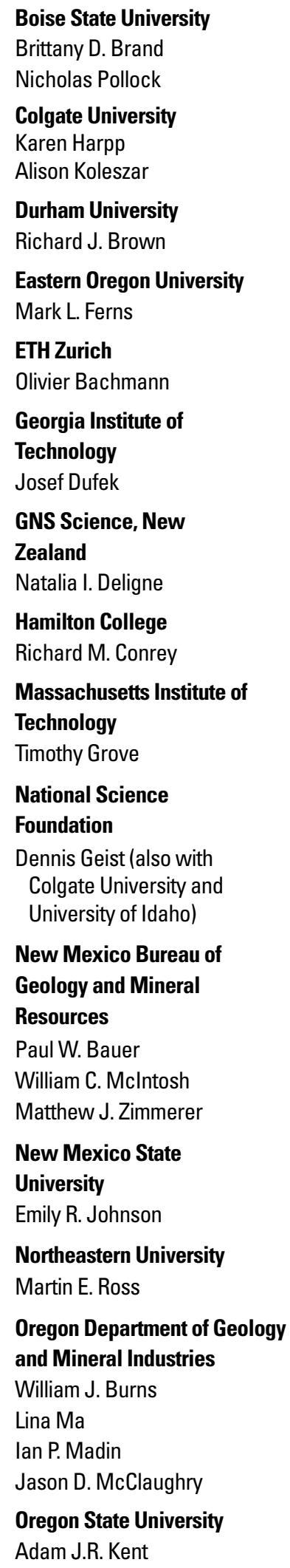

\author{
Portland State University \\ Jonathan H. Fink (also with \\ University of British Columbia) \\ Martin J. Streck \\ Ashley R. Streig
}

San Diego State University
Victor E Camp

Smithsonian Institution

Lee Siebert

Universidad Nacional

Autónoma de San Luis Potosi

Damiano Sarocchi

University of California, Davis

Kari M. Cooper

University of Liverpool

Peter B. Kokelaar

University of Northern

Colorado

Steven W. Anderson

University of Oregon

Ilya N. Binderman

Michael A. Dungan

Daniele Mckay (also with Oregon State University and Oregon State University, Cascades)

University of Portland Kristin Sweeney

University of Tasmania

Martin Jutzeler

Jocelyn McPhie

University of Utah

Jamie Farrell

U.S. Army Corps of

Engineers

Keith I. Kelson

\section{U.S. Forest Service}

Gordon E. Grant (also with Oregon State University)

\section{U.S. Geological Survey}

Charles R. Bacon

Andrew T. Calvert

Christine F. Chan

Robert L. Christiansen

Michael A. Clynne

Michael A. Cosca

Julie M. Donnelly-Nolan

Benjamin J. Drenth
William C. Evans

Judy Fierstein

Cynthia A. Gardner

V.J.S. Grauch

Christopher J. Harpel

Wes Hildreth

Richard P. Hoblitt

Robert A. Jensen

Peter W. Lipman

Jacob B. Lowenstern

Jon J. Major

Seth C. Moran

Lisa A. Morgan

Leah E. Morgan

L.J. Patrick Muffler

Jim O'Connor

John S. Pallister

Thomas C. Pierson

Joel E. Robinson

Juliet Ryan-Davis

Kevin M. Scott

William E. Scott

Wayne (Pat) Shanks

David R. Sherrod

Thomas W. Sisson

Mark Evan Stelten

Weston Thelen

Ren A. Thompson

Kenzie J. Turner

James W. Vallance

Alexa R. Van Eaton

Jorge A. Vazquez

Richard B. Waitt

Heather M. Wright

U.S. Nuclear Regulatory

Commission

Stephen Self (also with University of California, Berkeley)

Washington State University Joseph R. Boro

Owen K. Neill

Stephen P. Reidel

John A. Wolff

\section{Acknowledgments}

Juliet Ryan-Davis and Kate Sullivan created the overview map, and Vivian Nguyen created the cover design for this collection of field-trip guide books. The field trip committee is grateful for their contributions. 


\section{Contents}

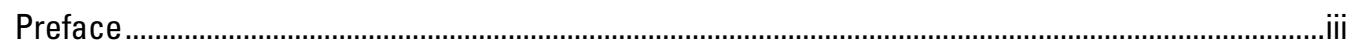

Contributing Authors .......................................................................................................................

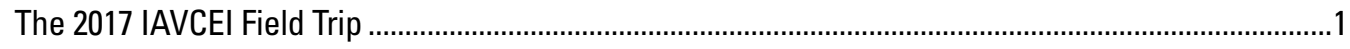

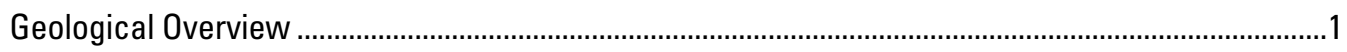

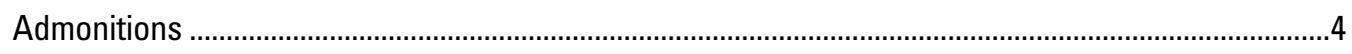

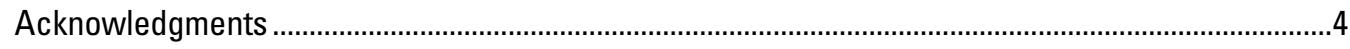

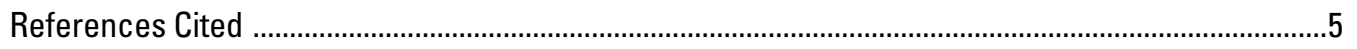

\section{Figures}

1. Index map for the field trip to the California Cascades.......................................................

2. Variation of $\mathrm{FeO}^{*} / \mathrm{MgO}$ versus $\mathrm{SiO}_{2}$ and $\mathrm{Na}_{2} \mathrm{O}$ versus $\mathrm{SiO}_{2}$ in lavas of the California Cascades................................................................................................................. 



\title{
Overview for Geologic Field-Trip Guides to Volcanoes of the Cascades Arc in Northern California
}

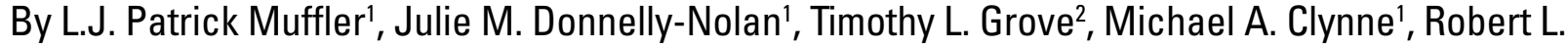 \\ Christiansen ${ }^{1}$, Andrew T. Calvert' ${ }^{1}$, and Juliet Ryan-Davis ${ }^{1}$
}

\section{The 2017 IAVCEI Field Trip}

This guidebook to volcanoes of the Cascades Volcanic Arc in Northern California (hereafter abbreviated as the California Cascades) was prepared for one of the field trips accompanying the quadrennial Scientific Assembly of the International Association of Volcanology and Chemistry of the Earth's Interior (IAVCEI) held in Portland, Oregon, in August 2017. The California Cascades field trip is a loop beginning and ending in Portland (fig. 1). The route of day 1 goes eastward across the Cascades just south of Mount Hood, travels south along the east side of the Cascades for an overview of the central Oregon volcanoes (including Three Sisters and Newberry Volcano), and ends at Klamath Falls, Oregon. Day 2 and much of day 3 focus on Medicine Lake Volcano. The latter part of day 3 consists of a drive south across the Pit River into the Hat Creek Valley and then clockwise around Lassen Volcanic Center to the town of Chester, California. Day 4 goes from south to north across Lassen Volcanic Center, ending at Burney, California. Day 5 and the first part of day 6 follow a clockwise route around Mount Shasta. The trip returns to Portland on the latter part of day 6, west of the Cascades through the Klamath Mountains and the Willamette Valley.

Each of the following three sections of this guidebook addresses one of the major volcanic regions: Lassen Volcanic Center (a volcanic field that spans the volcanic arc), Mount Shasta (a fore-arc stratocone), and Medicine Lake Volcano (a rear-arc, shield-shaped edifice). Each section of the guide provides (1) an overview of the extensive field and laboratory studies, (2) an introduction to the literature, and (3) directions to the most important and accessible field localities. The field-trip sections contain far more stops than can possibly be visited in the actual 6-day 2017 IAVCEI excursion from Portland. We have included extra stops in order to provide a field-trip guide that will have lasting utility for those who may have more time or may want to emphasize one particular volcanic area. Specific stops on the 2017 IAVCEI excursion will reflect the necessary logistic and time constraints.

\section{Geological Overview}

The Cascades Volcanic Arc in California consists of three major Quaternary volcanic centers: Medicine Lake Volcano, Lassen Volcanic Center, and Mount Shasta, as well as surrounding volcanic terrain. In the nearly three decades since the previous IAVCEI field trip to the region (Muffler and others, 1989), each of the Quaternary volcanic centers has been the subject of intensive interdisciplinary field studies, including geology, geochemistry, petrology, geochronology, paleomagnetism, and geophysics. Detailed eruptive histories have been established and characterized by detailed geologic mapping (Clynne and Muffler, 2010; Donnelly-Nolan, 2010; Calvert and Christiansen, 2011) and comprehensive chemical analyses (fig. 2). Experimental- and field-petrology studies have established the nature of mantle source regions for both the arc and the back-arc lavas and have elucidated the crystallization processes (under both wet and dry conditions) that have given rise to the compositional diversity observed in the lavas (for example, Bartels and others, 1991; Bullen and Clynne, 1990; Clynne, 1990; Grove and others, 1982; Grove and others, 1997; Grove and others, 2005). Wet (calc-alkaline) basalts are produced by interaction of fluids from the subducting slab with the mantle (Baker and others, 1994), whereas dry (tholeiitic) magmas are produced by near-anhydrous melting (Till and others, 2013) in the uppermost mantle wedge above the subducting slab. It is notable that both tholeiitic and calc-alkaline rocks erupt in close temporal and spatial proximity throughout the California Cascades.

Mount Shasta is a stratovolcano dominated by andesite and dacite produced by interaction of mantle-derived mafic magmas and a shallow crustal magma system. At an elevation of 14,179 ft (4,322 m), Mount Shasta rises over 10,000 ft $(3,000 \mathrm{~m})$ above the underlying terrain and dominates the skyline throughout much of northernmost California. Its eruptive volume over the past $600-700$ k.y. is $>400 \mathrm{~km}^{3}$, making it the largest stratovolcano in the Cascades; its eruption rate is $0.6 \mathrm{~km}^{3}$ per thousand years.

${ }^{1}$ U.S. Geological Survey.

${ }^{2}$ Massachusetts Institute of Technology. 


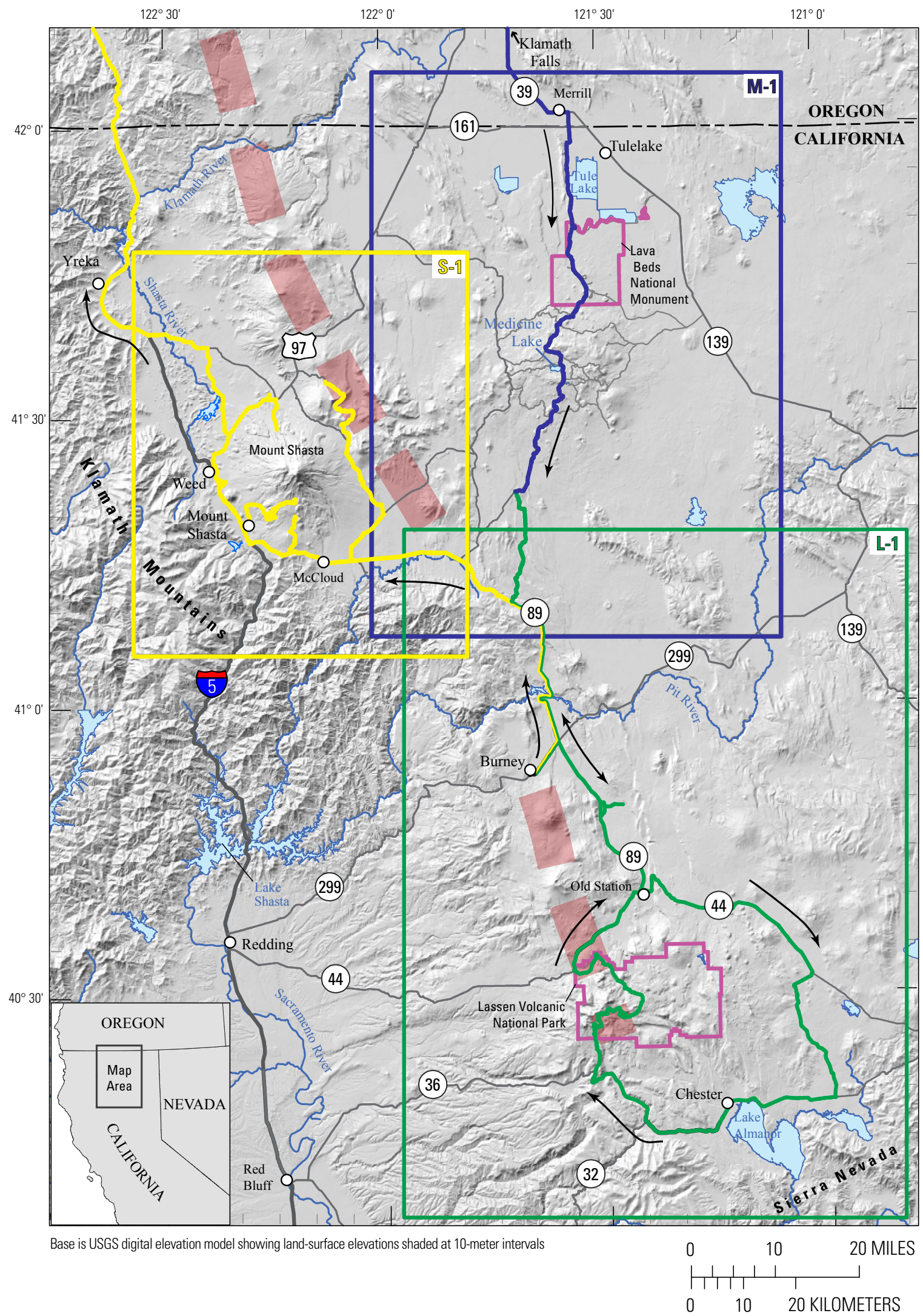

Figure 1. Index map for the field trip to the California Cascades. Generalized field-trip route shown as heavy colored lines. Axis of the Cascades Volcanic Arc shown by thick dashed red line. The colored rectangles designated M-1, S-1, and L-1 refer to the first figures in each of the Medicine Lake Volcano, Lassen Volcanic Center, and Mount Shasta chapters. These figures are more detailed maps of the field-trip route for those chapters. 

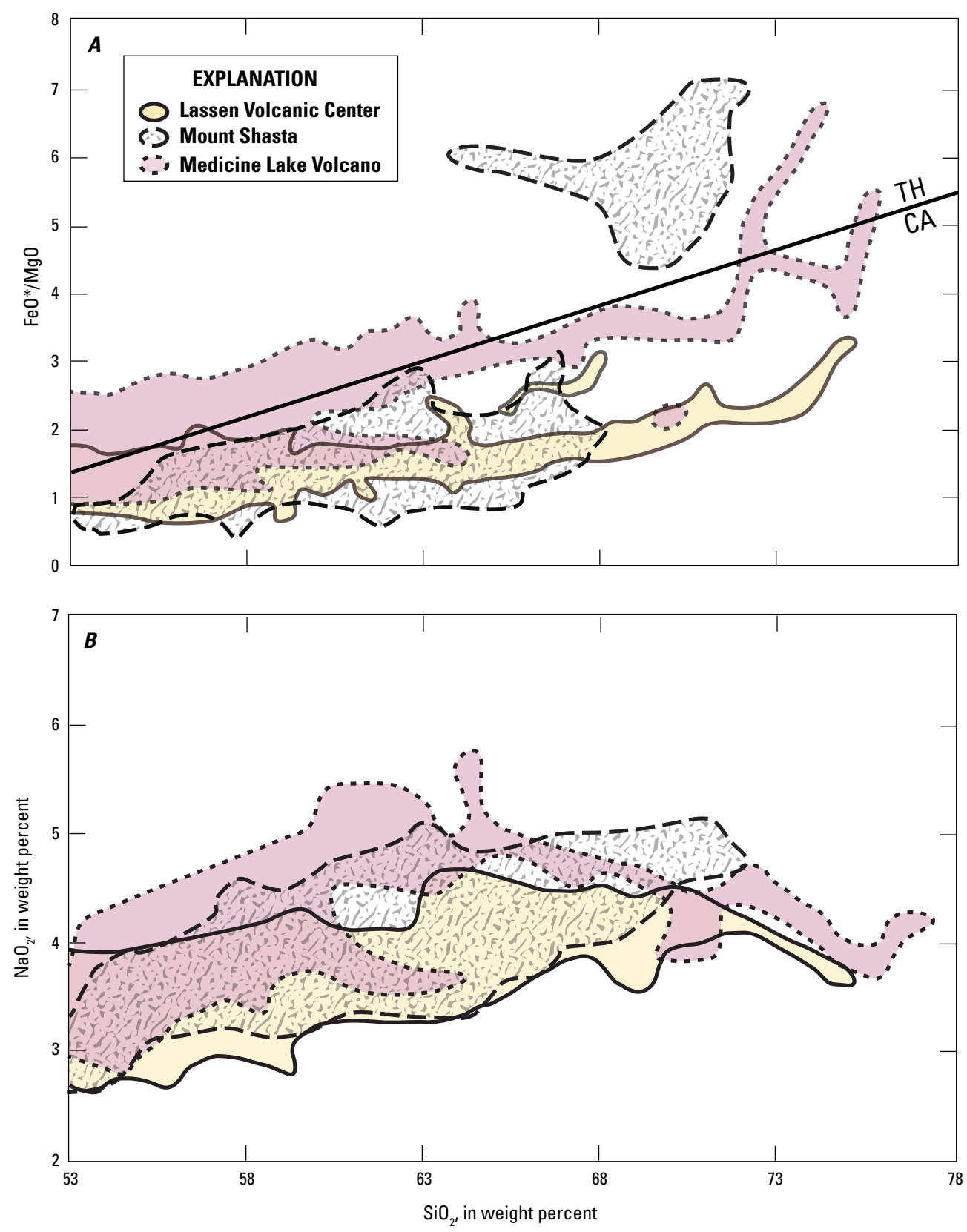

Figure 2. Variation of $\mathrm{FeO}^{*} / \mathrm{MgO}$ versus $\mathrm{SiO}_{2}(A)$ and $\mathrm{Na}_{2} \mathrm{O}$ versus $\mathrm{SiO}_{2}(B)$ in lavas of the California Cascades. Lassen Volcanic Center and Mount Shasta both exhibit very low $\mathrm{FeO} / \mathrm{MgO}$, some of lowest values found in arcs globally. Some lavas from Medicine Lake exhibit elevated $\mathrm{Na}_{2} \mathrm{O}$ contents as a consequence of crystallization under "moist" conditions (Mandler and others, 2014). Data sources: Lassen, 439 analyses from Clynne and others (2008); Medicine Lake, 268 analyses from Donnelly-Nolan (2008); Shasta, 75 analyses from Baker and others (1994), Grove and others (2002), and Grove and others (2005), plus 790 analyses from Christiansen (2017). The line dividing tholeiitic (TH) from calc-alkaline (CA) lavas is from Miyashiro (1974). Modified from figure 10 of Mandler and others (2014). 
In contrast to Mount Shasta, Medicine Lake Volcano is a broad, shield-shaped edifice that has erupted the full range of compositions, from primitive basalt to high-silica rhyolite. Most of its surface is mapped as mafic lavas (basalt to andesite), but geothermal drilling has identified a silicic core (Donnelly-Nolan and others, 2008; Donnelly-Nolan, 2010). Medicine Lake lavas record both dry and wet mantle melting, dry and wet crustal-level fractional crystallization, and open-system magma-chamber processes. At 7,913 ft (2,412 m) elevation, Medicine Lake Volcano rises only $\sim 4,300 \mathrm{ft}(\sim 1,300 \mathrm{~m})$ above the adjacent Modoc Plateau, but its lavas cover an area of $\sim 2,000 \mathrm{~km}^{2}$. Over the past $\sim 500$ k.y., Medicine Lake Volcano erupted a volume of $\sim 600 \mathrm{~km}^{3}$ (significantly more than the volume of Mount Shasta) with an eruption rate of $1.2 \mathrm{~km}^{3}$ per thousand years.

The Lassen region, in contrast to both Mount Shasta and Medicine Lake Volcano, is not a single prominent edifice, but instead is a laterally extensive, long-lived volcanic field (the Lassen Volcanic Center) with many dozens of vents (Clynne and Muffler, 2010). The dacite dome of Lassen Peak, at an elevation of 10,462 ft $(3,189 \mathrm{~m})$, rises nearly $6,000 \mathrm{ft}(\sim 1,800 \mathrm{~m})$ above the underlying, older volcanic centers (Muffler and Clynne, 2015). From $825 \mathrm{ka}$ to $600 \mathrm{ka}$, the Lassen Volcanic Center was a dacitic caldera complex, from $590 \mathrm{ka}$ to $390 \mathrm{ka}$ a true andesitic stratocone, and from $325 \mathrm{ka}$ to the present a silicic domefield. Repeated interaction of mantle-derived mafic magmas with a shallow body of rhyodacite crystal mush has produced a suite of mixed magmas (Clynne, 1999). Total volume of the eruptive products of the Lassen Volcanic Center is only $\sim 200 \mathrm{~km}^{3}$ over its lifetime of $825 \mathrm{k} . \mathrm{y}$., giving an eruption rate of only $0.24 \mathrm{~km}^{3}$ per thousand years.

All three volcanic centers have erupted in the Holocene, with the most recent magmatic eruptions being $\sim 3.1 \mathrm{ka}$ at Mount Shasta, $\sim 950$ years ago at Medicine Lake Volcano, and 102 years ago at Lassen Peak in the Lassen Volcanic Center.

Cascades volcanism is directly related to the subducting Juan de Fuca Plate (Bacon and others, 1997; Hildreth, 2007). Modern seismic investigations in the southern Cascades clearly show that the Juan de Fuca Plate is subducting under the North American Plate at a shallow angle (see figure 6a of McCrory and others, 2012). The Juan de Fuca slab surface is $90 \mathrm{~km}$ below the Lassen Volcanic Center, $70 \mathrm{~km}$ below Mount Shasta, and $85 \mathrm{~km}$ below Medicine Lake Volcano (figure $4 \mathrm{c}$ of McCrory and others, 2012).

Within the North American Plate, the Cascades Volcanic Arc in California is bounded by three major tectonic regimes: (1) the counterclockwise-rotating fore-arc blocks of southern Oregon and northwestern California (Wells and McCaffrey, 2013); (2) the Sierra Nevada block to the south; and (3) the Basin and Range Province to the east. Geodetic data show that all of these blocks are moving to the northwest at 5-11 mm per year relative to stable North America (Thatcher and others,
2014), but the exact boundaries between and among them are subject to conflicting interpretations. Impingement of the Basin and Range Province on the Lassen area and Medicine Lake Volcano is expressed both by normal faults and by vent alignments controlled by these faults (for example, Muffler and others, 2011).

The right-lateral Walker Lane separates the Sierra Nevada block from the Basin and Range Province to the east (Faulds and Henry, 2008). This broad, linear zone of distributed dextral strike-slip faulting, parallel to and inboard of the San Andreas Fault System, accommodates about 20 percent of the relative motion between the North American and Pacific Plates (Unruh, 1995). The California Cascades can be considered a transitional zone, where horizontal stress is transferred from northwest-southeast dextral shear of the Walker Lane to dominantly east-west extension of the Cascade Range in Oregon (Blakely and others, 1997).

The Lassen Volcanic Center overlies several older ( 2.4-1.1 Ma) volcanic centers, with a few windows into Paleozoic and Mesozoic igneous and metamorphic rocks and Cretaceous sedimentary rocks. Mount Shasta, being west of the Cascade axis, lies directly on Paleozoic sedimentary and metamorphic rocks, although numerous mafic centers ranging in age from 6 to $1.2 \mathrm{Ma}$ define an east-northeast-trending highland between Medicine Lake and Mount Shasta. No basement rocks are exposed near Medicine Lake Volcano, nor were older rocks penetrated by geothermal drilling. The terrain of Tertiary volcanoes and shallow plutons termed the "Western Cascades" in Oregon extends south only to the northern part of the Mount Shasta region.

\section{Admonitions}

Collecting rock samples in Lassen Volcanic National Park and in Lava Beds National Monument is prohibited without a special permit from the National Park Service. Please abide by this restriction.

Several of the field-trip stops are along busy, dangerous highways. Be aware of fast-moving traffic, particularly large trucks. Look both ways before attempting to cross a highway. Be alert and be careful!

\section{Acknowledgments}

We acknowledge technical reviews by Marianne Guffanti and Thomas Giachetti for all four sections of this field-trip guide, as well as the careful editing by Katherine Jacques, Claire Landowski, and Jan Zigler. 


\section{References Cited}

Bacon, C.R., Bruggman, P.E., Christiansen, R.L., Clynne, M.A., Donnelly-Nolan, J.M., and Hildreth, W., 1997, Primitive magmas at five Cascade volcanic fields - melts from hot, heterogeneous sub-arc mantle: The Canadian Mineralogist, v. 35 , p. $397-423$.

Baker, M.B., Grove, T.L., and Price, R., 1994, Primitive basalts and andesites from the Mt. Shasta region, N. CaliforniaProducts of varying melt fraction and water content: Contributions to Mineralogy and Petrology, v. 118, p. 111-129.

Bartels, K.S., Kinzler, R.J., and Grove, T.L., 1991, High pressure phase relations of primitive high-alumina basalts from Medicine Lake volcano, northern California: Contributions to Mineralogy and Petrology, v. 108, p. $253-270$.

Blakely, R.J., Christiansen, R.L., Guffanti, M., Wells, R.E., Donnelly-Nolan, J.M., Muffler, L.J.P., Clynne, M.A., and Smith, J.G., 1997, Gravity anomalies, Quaternary vents, and Quaternary faults in the southern Cascade Range, Oregon and California - implications for arc and backarc evolution: Journal of Geophysical Research, v. 102, no. B10, p. 22513-22527.

Bullen, T.D., and Clynne, M.A., 1990, Trace element and isotopic constraints on magmatic evolution at Lassen Volcanic Center: Journal of Geophysical Research, v. 95, p. 19671-19691.

Christiansen, R.L., Calvert, A.T., Fierstein, J.E., Gardner, C.A., and Zeichert, T.A., 2017, Chemical and isotopic analyses of Mount Shasta, California: U.S. Geological Survey data release, https://doi.org/10.5066/F7XK8DFP.

Clynne, M.A., 1990, Stratigraphic, lithologic, and major element geochemical constraints on magmatic evolution at Lassen Volcanic Center, California: Journal of Geophysical Research, v. 95, p. 19651-16669.

Clynne, M.A., 1999, Complex magma mixing origin for multiple volcanic lithologies erupted in 1915 from Lassen Peak, California: Journal of Petrology, v. 40, p. 105-132.

Clynne, M.A., Muffler, L.J.P., Siems, D.F., Taggart, J.E., Jr., and Bruggman, P., 2008, Major and EDXRF trace-element chemical analyses of volcanic rocks from Lassen Volcanic National Park and vicinity: U.S. Geological Survey OpenFile Report 2008-1091, 11 p. [Also available online at http:// pubs.usgs.gov/of/2008/1091/].
Clynne, M.A., and Muffler, L.J.P., 2010, Geologic map of Lassen Volcanic National Park and vicinity, California: U.S. Geological Survey Scientific Investigations Map 2899, scale 1:50,000.

Donnelly-Nolan, J.M., 2008, Chemical analyses of pre-Holocene rocks from Medicine Lake volcano and vicinity, Northern California: U.S. Geological Survey Open-File Report 20081094, http://pubs.usgs.gov/of/2008/1094/.

Donnelly-Nolan, J.M., 2010, Geologic map of Medicine Lake Volcano, northern California: U.S. Geological Survey Scientific Investigations Map 2927, scale 1:50,000.

Donnelly-Nolan, J.M., Grove, T.I., Lanphere, M.A., Champion, D.E., and Ramsey, D.W., 2008, Eruptive history and tectonic setting of Medicine Lake Volcano, a large rear-arc volcano in the southern Cascades: Journal of Volcanology and Geothermal Research, v. 177, p. 313-328.

Faulds, J.E., and Henry, C.D., 2008, Tectonic influences on the spatial and temporal evolution of the Walker Lane: An incipient transform fault along the evolving Pacific-North American plate boundary: Arizona Geological Society Digest 22, p. $437-470$.

Grove, T.L., Baker, M.B., Price, R.C., Parman, S.W., ElkinsTanton, L.T., Chatterjee, N., Müntener, O., 2005, Magnesian andesite and dacite lavas from Mt. Shasta, northern California - products of fractional crystallization of $\mathrm{H}_{2} \mathrm{O}$-rich mantle melts: Contributions to Mineralogy and Petrology, v.148, p. 542-565, doi:10.1007/s00410-004-0619-6.

Grove, T.I., Donnelly-Nolan, J.M., and Housh, T., 1997, Magmatic processes that generated the rhyolite of Glass Mountain, Medicine Lake volcano, N. California: Contributions to Mineralogy and Petrology, v. 127, p. 205-223.

Grove, T.L., Gerlach, D.C., and Sando, T.W., 1982, Origin of calcalkaline series lavas at Medicine Lake volcano by fractionation, assimilation and mixing: Contributions to Mineralogy and Petrology, v. 80, p. 160-182.

Grove, T.L., Parman, S.W., Bowring, S.A., Price, R.C., and Baker, M.B., 2002, The role of an $\mathrm{H}_{2} \mathrm{O}$-rich fluid component in the generation of primitive basaltic andesites and andesites from the Mt. Shasta region, N. California: Contributions to Mineralogy and Petrology, v. 142, p. 375-396.

Hildreth, W., 2007, Quaternary magmatism in the Cascadesgeological perspectives: U.S. Geological Survey Professional Paper 1744, $125 \mathrm{p}$. 
Mandler, B.E., Donnelly-Nolan, J.M., and Grove, T.L., 2014, Straddling the tholeiitic/calc-alkaline transition - the effects of modest amounts of water on magmatic differentiation at Newberry Volcano: Contributions to Mineralogy and Petrology, v. 168, article 1066, 25 p., doi:10.1007/s00410014-1066-7.

McCrory, P.A., Blair, J.L., Waldhauser, F., and Oppenheimer, D.H., 2012, Juan de Fuca slab geometry and its relation to Wadati-Benioff zone seismicity: Journal of Geophysical Research, v. 117, article B09306, 23 p., doi: 10.1029/2012JB009407.

Miyashiro, A., 1974, Volcanic rock series in island arcs and active continental margins: American Journal of Science, v. 274, p. 321-355.

Muffler, L.J.P., Bacon, C.R., Christiansen, R.L., Clynne, M.A., Donnelly-Nolan, J.M., Miller, C.D., Sherrod, D.R., and Smith, J.G., 1989, South Cascades arc volcanism, California and southern Oregon, in Chapin, C.E., and Zidek, J, eds., Field excursions to volcanic terranes in the western United States, Volume II-Cascades and Intermountain West: New Mexico Bureau of Mines and Mineral Resources, Memoir 47, p. 183225.

Muffler, L.J.P., and Clynne, M.A., 2015, Geologic field-trip guide to Lassen Volcanic National Park and vicinity: U.S. Geological Survey Scientific Investigations Report 20155067, $67 \mathrm{p}$.
Muffler, L.J.P., Clynne, M.A., Calvert, A.T., and Clynne, M.A., 2011, Diverse, discrete mantle-derived batches of basalt erupted along a short normal fault zone - the Poison Lake chain, southernmost Cascades: Geological Society of America Bulletin, v. 123, p. 2177-2200.

Thatcher, W., Simpson, R.W., Svarc, J.L., and Lisowski, M., 2014, Present-day deformation in northeastern California, northwestern Nevada, and southern Oregon [abs.]: American Geophysical Union, 2014 fall meeting, abstract G11A-465, accessed June 13, 2017, at http://abstractsearch.agu.org/ meetings/2014/FM/G11A-0465.html.

Till, C.B., Grove, T.L., Carlson, R.W., Fouch, M.J., DonnellyNolan, J.M., Wagner, L.S., and Hart, W.K., 2013, Depths and temperatures of $<10.5 \mathrm{Ma}$ mantle melting and lithosphereasthenosphere boundary below southern Oregon and northern California: Geochemistry, Geophysics, Geosystems, v. 14, no. 4, p. 864-879, doi:10.1002/ggge.20070.

Unruh, J.R., 1995, Late Cenozoic tectonics of the Greater Walker Lane Belt and implications for active deformation in the Lake Almanor Region, northeastern California, in Page, W.D., ed., Quaternary geology along the boundary between the Modoc Plateau, southern Cascade Mountains, and northern Sierra Nevada: Friends of the Pleistocene, 1995 Pacific Cell Field Trip Guide, appendix B, 11 p.

Wells, R.E., and McCaffrey, R., 2013, Steady rotation of the Cascade arc: Geology, v. 41, no. 9, p. 1027-1030. 
Menlo Park Publishing Service Center, California

Manuscript approved June 2, 2017

Edited by Katherine Jacques, Claire Landowski, and Jan Zigler Layout by Cory Hurd 


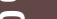

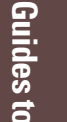

을

宕

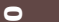

节

䘦

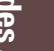

국

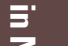

赇

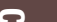

承

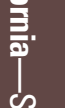

d

高.

$\overrightarrow{\bar{z}}$

.

.

응

テ̃

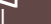

颂
$\frac{1}{\lambda}$ 